\title{
ANALISIS FAKTOR-FAKTOR YANG MEMPENGARUHI MINAT NASABAH TERHADAP PRODUK TABUNGAN PENDIDIKAN BERASURANSI PADA BANK SYARIAH MANDIRI CABANG KOTA BOGOR
}

\section{ANALYSIS OF FACTORS THAT INFLUENCE CUSTOMER INTERESTS ON PRODUCTS OF INSURED EDUCATION SAVINGS IN MANDIRI SHARIA BANKS BRANCH BOGOR CITY}

\author{
Khoirani1a; Andri Brawijaya²; M. Komaruddin³; \\ ${ }^{1}$ Program Studi Perbankan Syariah Fakultas Ekonomi Islam Universitas Djuanda, Jl. Tol Ciawi No. 1, \\ Kotak Pos 35 Bogor 16720 \\ 2Program Studi Perbankan Syariah Fakultas Ekonomi Islam Universitas Djuanda, Jl. Tol Ciawi No. 1, \\ Kotak Pos 35 Bogor 16720 \\ ${ }^{3}$ Program Studi Perbankan Syariah Fakultas Ekonomi Islam Universitas Djuanda, Jl. Tol Ciawi No. 1, \\ Kotak Pos 35 Bogor 16720 \\ aKorespondensi: Khoirani, e-mail: rahmatul.wadah@unida.ac.id.
}

\begin{abstract}
The purpose of this study was to find out how customers' responses to insurance education savings products and any factors that affect partially and simultaneously affect customer interest. The research method is a survey, a form of quantitative research and a type of data ratio with the object of research as many as 100 customers who use insurance education savings products in the city of Bogor. Based on the results of the study, simultaneously and partially the variables consisting of Service, Reputation, Religiosity, and Revenue have a positive and significant effect on customer interest in educational savings products in the branch branch of the Bogor Islamic sharia bank.

Keyword: Insurance, Service, Information, Reputation, Religiosity and income education savings
\end{abstract}

\section{ABSTRAK}

Penelitian ini bertujuan untuk mengetahui bagaimana tanggapan nasabah tentang produk tabungan pendidikan berasuransi dan faktor apa saja yang dapat mempengaruhi secara parsial dan simultan terhadap minat nasabah. Metode penelitian adalah survei, bentuk penelitian kuantitatif dan jenis data rasio dengan objek penelitian sebanyak 100 nasabah yang menggunakan produk tabungan pendidikan berasuransi di Kota Bogor. Berdasarkan hasil penelitian, secara simultan dan parsial variabel yang terdiri dari Pelayanan, Informasi, Reputasi, dan Pendapatan berpengaruh positif dan signifikan dan adapun faktor religiusitas yang tidak berpengaruh tetapi signifikan terhadap minat nasabah produk tabungan pendidikan berasuransi pada bank syariah mandiri cabang Kota Bogor.

Kata Kunci: Tabungan pendidikan berasuransi, Pelayanan, Informasi, Reputasi, Religiusitas dan pendapatan.

Khoirani. 2020. Analisis Faktor-Faktor Yang Mempengaruhi Minat Nasabah Terhadap Produk Tabungan Pendidikan Berasuransi Pada Bank Syariah Mandiri Cabang Kota Bogor. Jurnal Nisbah 6 (1): 42-48. 


\section{PENDAHULUAN}

Perkembangan industri keuangan di Indonesia termasuk cukup cepat. Menurut Otoritas Jasa Keuangan (2018), Jika dilihat perkembangan asuransi di Indonesia baik itu asuransi syariah maupun asuransi konvensional, merujuk pada data yang tertera pada lembaga pengawas keuangan yaitu otoritas jasa keuangan (OJK) telah menyatakan bahwa pertumbuhan pada aset keuangan asuransi syariah saat ini telah mencapai 42,7 triliun hingga bulan maret 2018. Jumlah tersebut mengalami kenaikan sebesar 21,3\% dari tahun 2017 (OJK, 2018).

Pada saat ini perusahaan asuransi dan perusahaan reasuransi dengan prinsip syariah per 31 Desember 2017 berjumlah 63 perusahaan, 12 perusahaan asuransi syariah (murni syariah) 1 perusahaan reasuransi syariah (murni syariah), 48 perusahaan asuransi unit syariah dan 2 perusahaan reasuransi unit syariah.

Sementara itu, untuk pangsa pasar asuransi syariah sendiri terbilang kecil jika dibandingkan dengan konvensional, maka dari itu masih sulit bagi asuransi syariah mengejar ketinggalan dari asuransi konvensional. Hal ini dapat ditinjau melalui pangsa pasar keuangan syariah yang ada secara keseluruhan masih dibawah $5 \%$.

Seiring berkembangnya sektor perbankan, kini telah hadir inovasi pada sektor jasa keuangan, yaitu berkembangnya bancassurance. Bancassurance adalah suatu sistem penggabungan kerjasama antara bank dengan lembaga asuransi dimana sistem nya berupa penjualan suatu produk asuransi yang pendistribusiannya melalui bank, dengan demikian terjadi kemitraan antara pihak perusahaan asuransi dan bank dalam produk bancassurance). Dari beberapa jenis pendanaan, BSM meluncurkan produk dengan inovasi terbaru yaitu tabungan pendidikan berjangka yang sifatnya berasuransi dan termasuk kedalam fitur bancassurance. Tabungan berjangka ini tabungan yang memiliki tujuan untuk meringankan keperluan uang pendidikan dengan jumlah setoran yang tetap serta dilengkapi dengan perlindungan asuransi. BSM tabungan pendidikan berasuransi ini menggunakan prinsip Mudharabah Mutlaqah, produk yang diperuntukkan untuk pendidikan anak ini telah lama ditawarkan hanya saja sejauh ini tidak banyak nasabah yang mengetahui produk ini (khoiriyah, 2011:5).

Menabung adalah bagian dari bentuk investasi yang banyak dilakukan oleh semua masyarakat, termasuk di Indonesia. Baik digunakan untuk kebutuhan seharihari ataupun untuk perencanaan masa depan, serta baik untuk diri sendiri ataupun rancangan masa depan anak dan keluarga. Hadirnya produk tabungan investasi berjangka pada BSM sebagai salah satu bentuk peduli terhadap perencanaan masa depan yang dapat meringankan risiko yang kemungkinan terjadi. Tabungan berjangka ini ditujukan untuk keperluan dana pendidikan anak dengan jumlah setoran tetap setiap bulannya yang disertai perlindungan asuransi.

Penabung pemilik tabungan ini berhak mendapat manfaat perlindungan asuransi dari perusahaan asuransi yang telah disetujui bank untuk bekerjasama dalam produk Tabungan pendidikan berasuransi. Atas perlindungan asuransi tersebut, perusahaan asuransi akan menerbitkan sertifikat (bukti kepesertaan) asuransi dan perlindungan asuransinya berlaku efektif pada tanggal pembukaan rekening TIC. Adapun hal-hal yang menyangkut perlindungan asuransi tunduk pada syarat/ketentuan yang ditentukan oleh perusahaan asuransi.

Dari uraian diatas dapat disimpulkan bahwa kehidupan manusia semakin hari tidak pernah luput dari ancaman dan juga risiko yang berbahaya. Ancaman dan risiko tersebut bisa dipicu dari kelemahan diri sendiri, kesalahan-kesalahan yang diperbuat, dan tidak mengertinya terhadap masalah yang akan dihadapi (BSM, diakses tanggal 20 Januari 2019 Pukul 17.00 WIB). 


\section{MATERI DAN METODE}

\section{Tabungan Pendidikan Berasuransi}

Tabungan Pendidikan Berasuransi merupakan produk tabungan berjangka untuk keperluan uang pendidikan dengan jumlah setoran bulanan tetap (installment) dan dilengkapi dengan perlindungan asuransi (Febriasti,2017:34)

\section{Atribut Variabel X (Faktor-Faktor)}

1. Pelayanan

2. Informasi

3. Reputasi

4. Religiusitas

5. Pendapatan

\section{Minat Beli}

Menurut Yamit (2001:77) minat beli konsumen/nasabah adalah bentuk dari sebuah evaluasi purna beli nasabah atau hasil evaluasi yang telah dilakukan nasabah dalam melakukan perbandingan apa yang telah dirasakan dengan harapannya.

\section{Indikator Minat beli}

Indikator di dalam penelitian ini Menurut Kambuaya (2015:105), minat beli dapat diidentifikasikan melalui indikatorindikator sebagai berikut :

\section{Minat Tanggapan \\ 2. Minat Pandangan \\ 3. Minat Gambaran}

\section{Desain Penelitian}

Penelitian ini menggunakan jenis penelitian kuantitatif. Menurut Sugiyono (2009:29) menyatakan bahwa metode kuantitatif adalah suatu metode yang berfungsi untuk mendeskripsikan atau memberi gambaran terhadap objek yang diteliti melalui data atau sampel yang telah terkumpul sebagaimana adanya tanpa melakukan analisis dan membuat kesimpulan yang berlaku untuk umum. Dalam penelitian ini akan digunakan bentuk penelitian kuantitatif yang dilaksanakan melalui pengumpulan data pada nasabah tabungan Investasi Cendekia pada Bank Syariah Mandiri di sekitar Kota Bogor. Penelitian kuantitatif menurut Sugiyono (2013: 206) merupakan penelitian yang bertujuan untuk mengetahui hubungan antara dua variabel atau lebih melalui pengumpulan data dilapangan, sifat kuantitatif pada dasarnya ingin menguji kebenaran dari suatu hipotesis yang dilaksanakan melalui pengumpulan data di lapangan.

\section{Populasi, Sampel dan Teknik Pengambilan Sampel}

Populasi dalam penelitian ini adalah seluruh nasabah tabungan investasi cendekia pada Bank Syariah Mandiri di Cabang Kota Bogor. Dalam penelitian ini, jumlah populasi yang digunakan dari nasabah Tabungan Investasi Cendikia tidak diketahui dengan pasti jumlahnya. Sehingga teknik pengambilan sampel menggunakan teknik atau pendekatan non probability sampling dengan metode incindential sampling. Menurut Sugiyono (2014:156), incendental sampling merupakan teknik dalam penentuan pengambilan sampel berdasarkan kebetulan dengan keadaan yang tidak sengaja, yaitu peneliti yang kebetulan/insidental bertemu dengan siapa saja dapat dijadikan sebagai sampel, bila dipandang peneliti bahwa orang yang ditemui itu cocok sebagai sumber data.

\section{Metode Pengujian Data}

\section{Uji Validitas}

Sugiyono (2014:203) menyatakan bahwa instrumen valid berarti alat ukur yang digunakan untuk mendapatkan data (mengukur) itu valid.

\section{Uji Reliabilitas}

Menurut Sugiyono (2014:203) instrumen yang reliabel adalah instrumen yang jika digunakan berkali-kali untuk mengukur suatu objek yang sama dapat menghasilkan data yang sama atau jika jawaban seseorang terhadap pertanyaan adalah konsisten atau stabil dari waktu ke waktu.

\section{Metode Analisis Data}

\section{Analisis Regresi Linear Berganda}

Menurut Sugiyono (2014:277) bahwa: Regresi linier berganda dimaksudkan untuk meramal keadaan (naik turunnya) variabel dependen, apabila dua atau lebih 
variabel independen sebagai faktor prediator dimanipulasi (dinaik turunkan nilainya).

maka hubungan antara variabel penelitian dapat diungkapkan dalam model sebagai berikut:

\section{Keterangan:}

$\boldsymbol{\varepsilon}$ : Faktor lain yang tidak diteliti

$\longrightarrow$ Pengaruh Parsial

$\rightarrow$ Pengaruh Simultan

$\longrightarrow$ Pengaruh error

variabel lain

Model hubungan pelayanan, informasi, reputasi, religiusitas dan pendapatan minat dalam fungsi atau persamaan sebagai berikut:

$$
\begin{aligned}
& Y=a+\beta 1 X 1+\beta 2 X 2+\beta 3 X 3 \\
& +\beta 4 X 4+\beta 5 X 5+\varepsilon
\end{aligned}
$$

Keterangan :

Y : Minat nasabah

A : Bilangan konstanta

$\beta_{1}$ : Koefisien regresi untuk mengetahui sejauh mana pengaruh pelayanan terhadap minat nasabah.

$\beta_{2}$ : Koefisien regresi untuk mengetahui sejauh mana pengaruh informasi terhadap minat nasabah.

$\mathrm{B}_{3} \quad$ Koefisien regresi untuk mengetahui sejauh mana pengaruh reputasi terhadap minat nasabah

$\mathrm{B}_{4} \quad$ Koefisien regresi untuk mengetahui sejauh mana pengaruh religiusitas terhadap minat nasabah

$\mathrm{B}_{5} \quad$ Koefisien regresi untuk mengetahui sejauh mana pengaruh pendapatan terhadap minat nasabah

$\varepsilon \quad$ Faktor lain yang tidak diteliti.

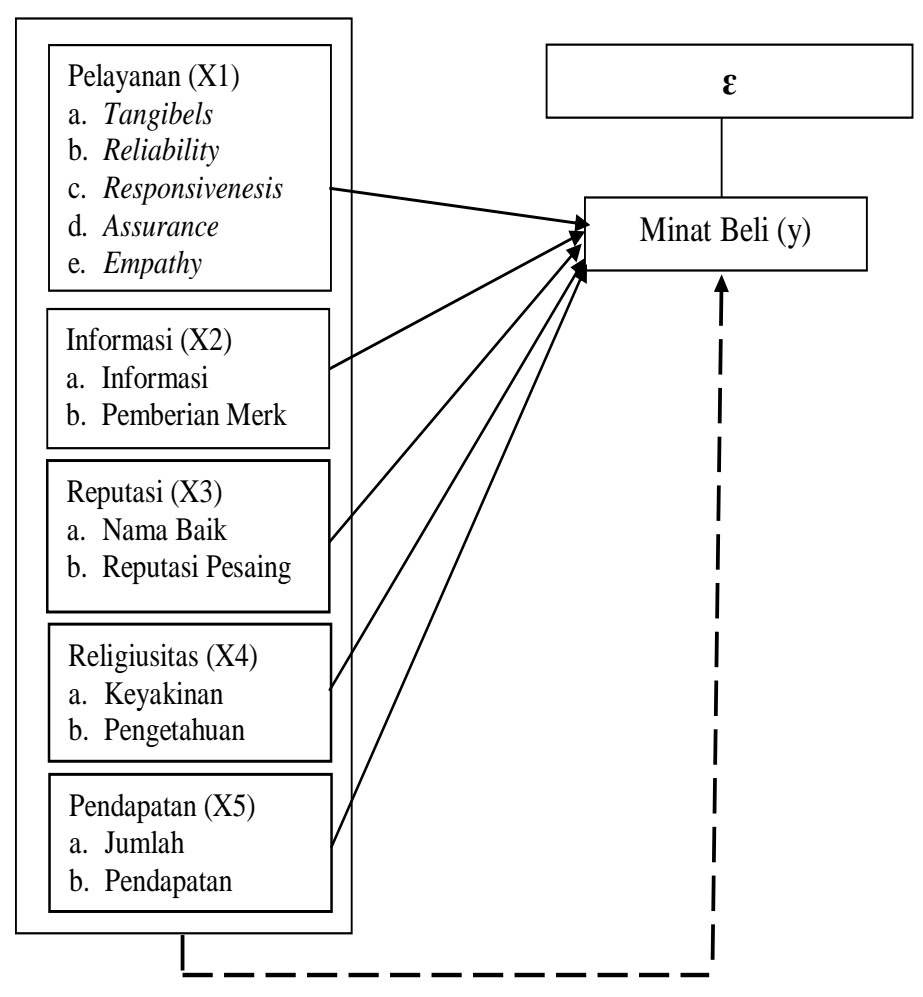

\section{Gambar 3.2 Hubungan Antara Variabel Penelitian}

\section{Analisis Korelasi Berganda}

Korelasi Berganda merupakan angka yang menunjukkan letaknya arah dan kuatnya suatu hubungan antara dua atau lebih variabel $X$ secara bersama sama dengan satu variabel $Y$ (Sugiyono, 2014:286). Untuk mengetahui bagaimana hubungan antara faktor-faktor yang dapat mempengaruhi dengan minat nasabah terhadap Tabungan Investasi Cendekia di Kota Bogor maka digunakan rumus sebagai berikut:

$$
=\frac{n \sum \quad X i Y-\left(\sum \quad X i\right)\left(\begin{array}{ll}
\sum & Y
\end{array}\right)}{\sqrt{\left\{n \sum \quad X i Y-\left(\begin{array}{lll}
n & X i
\end{array}\right)\left(\begin{array}{ll}
\sum & Y
\end{array}\right)\right\}}}
$$

Dari rumus analisis korelasi diatas, maka akan diperoleh nilai $r$ yang besarnya antara $-1,0$ sampai 1. Notasi ini menggunakan korelasi atau hubungan antara variabel-variabel yang diuji dalam penelitian.

1. Apabila $r=0$ atau mendekati 0 , maka tidak ada hubungan antara kedua 
variabel atau hubungan kedua variabel sangat lemah

2. Apabila $r=1$ atau mendekati 1 , maka hubungan kedua variabel bersifat searah dan sangat kuat, artinya kenaikan nilai-nilai $\mathrm{X}$ akan diikuti oleh kenaikan nilai-nilai $Y$, atau sebaliknya.

3. Apabila $r=-1$ atau mendekati -1 , maka hubungan antara kedua variabel berlawanan arah dan sangat kuat, artinya kenaikan nilai-nilai $\mathrm{X}$ akan diikuti oleh penurunan nilai-nilai $Y$, atau sebaliknya.

\section{Analisis Koefisien Determinasi}

Analisis koefisien determinasi digunakan untuk melihat sejauh mana keseluruhan variabel independen dapat menjelaskan variabel dependen Atmaja (2009:122).

Koefisien determinasi dihitung dengan rumus sebagai berikut:

$$
K D=r^{2} \times 100 \%
$$

Keterangan:

$$
\begin{aligned}
& \text { KD : Koefisien } \\
& \text { Determinasi r } \mathrm{x} \\
& \text { Koefisien korelasi }
\end{aligned}
$$

\section{Pengujian Hipotesis}

Uji statistik $\mathrm{F}$ digunakan untuk menguji apakah variabel independen yang dimaksud dalam model memiliki pengaruh secara bersama-sama (simultan) terhadap variabel dependen. Dengan level signifikansi yang ditetapkan adalah 5\% atau derajat kebebasan 95\%. uji statistik t digunakan untuk menguji apakah variabel independen yang dimasukkan kedalam model yang memiliki pengaruh secara individual (parsial) terhadap variabel dependen dengan menggunakan tingkat signifikansi 5\%.

\section{HASIL DAN PEMBAHASAN}

Tabel 4.1

\section{Rekapitulasi Karakteristik Konsumen}

\begin{tabular}{ccccc} 
No & $\begin{array}{c}\text { Jenis } \\
\text { Karakteris } \\
\text { tik }\end{array}$ & $\begin{array}{c}\text { Ciri-ciri } \\
\text { Konsumen }\end{array}$ & $\begin{array}{c}\text { Jumla } \\
\mathbf{h} \\
\text { Konsu }\end{array}$ & $\begin{array}{c}\text { Perse } \\
\text { ntase } \\
(\%)\end{array}$ \\
\hline
\end{tabular}

\begin{tabular}{lllcc}
\hline & & & men & \\
\hline 1 & Jenis & Perempuan & 59 & 59 \\
2 & Kelamin & 33-38 & 57 & 57 \\
3 & Usia & Tahun & 78 & 78 \\
4 & Tingkat & S1 & 72 & 72 \\
5 & Pendidikan & Karyawan & 58 & 58 \\
& Tingkat & Swasta & & \\
& Pekerjaan & $>$ Rp. & & \\
& Pendapatan & 5.000 .000 & & \\
& & & &
\end{tabular}

Berdasarkan Tabel 4.1 tersebut bahwa karakteristik nasabah terbanyak jenis kelamin perempuan, usia 33-38 tahun sedangkan tingkat pendidikan terakhir S1 dengan pekerjaan Karyawan Swasta, pendapatan perbulan sebesar > Rp. 5.000.000, dan sudah menggunakan tabungan investasi cendekia pada BSM Cabang Kota Bogor.

\section{Hasil Analisis Regresi Linear Berganda}

Berdasarkan perhitungan analisis regresi linear berganda dengan menggunakan alat bantu SPSS, maka dapat diketahui persamaan regresi sebagai berikut:

$$
\begin{gathered}
\text { Y= 0,189 + 4,877 } \\
\text { Pelayanan }+\mathbf{1 , 5 1 0} \\
\text { Informasi }+2,209 \text { Reputasi } \\
-\mathbf{0 , 0 5 0} \text { Religiusitas }+\mathbf{5 , 0 6 8} \\
\text { Pendapatan }+\varepsilon \\
\text { persamaan regresi tersebut }
\end{gathered}
$$
diketahui bahwa Pelayanan $\left(\mathrm{X}_{1}\right)$, Informasi $\left(\mathrm{X}_{2}\right)$ bernilai positif, Reputasi $\left(\mathrm{X}_{3}\right)$ bernilai positif, Religiusitas $\left(\mathrm{X}_{4}\right)$ bernilai negatif dan Pendapatan $\left(\mathrm{X}_{5}\right)$ bernilai positif. Sehingga menunjukkan semakin tinggi nilai dari empat variabel tersebut, maka minat beli / guna nasabah tabungan investasi cendekia bank syariah cabang Kota Bogor akan semakin tinggi.

\section{Analisis Korelasi Berganda}

Model Summary

\begin{tabular}{lcrrr}
\hline Model & & $\mathrm{R}$ & $\begin{array}{c}\text { Adjusted } \\
\text { Square }\end{array}$ & $\begin{array}{c}\text { Std. Error } \\
\text { of the } \\
\text { Estimate }\end{array}$ \\
\hline 1 &, 78 &, 610 &, 590 &, 15455 \\
& $1^{\mathrm{a}}$ & & & \\
\hline
\end{tabular}

a. Predictors : (Constant), X2,X3,X4,X5, X1 
b. Dependent Variable: Y

Berdasarkan Tabel 4.2 diketahui nilai $\mathrm{R}$ adalah 0,792 yang berada pada kategori kuat $(0,601-0,800)$ hal ini menunjukan bahwa hubungan antara variabel Pelayanan

$\left(\mathrm{X}_{1}\right)$, Informasi $\left(\mathrm{X}_{2}\right), \quad$ Reputasi $\left(\mathrm{X}_{3}\right)$, Pendapatan $\left(\mathrm{X}_{5}\right)$ dengan variabel Minat nasabah (Y) tabungan Investasi Cendekia Cabang Kota Bogor memiliki hubungan yang kuat.

\section{Koefisien Determinasi $\left(\mathbf{R}^{\mathbf{2}}\right)$}

Koefisien determinasi bertujuan untuk mengetahui seberapa besar persentase sumbangan pengaruh variabel independen secara serentak terhadap variabel dependen. Berdasarkan Tabel 4.2 tersebut juga dapat diketahui bahwa $R$ Square sebesar 0,610 atau 61\%. Hal ini menunjukan bahwa persentase sumbangan pengaruh variable Independen/ variabel bebas terhadap Minat Beli adalah sebesar $61 \%$. Besarnya pengaruh faktor-faktor lain yang tidak diteliti dalam penelitian ini sebesar 39\% dipengaruhi variabel lain seperti Perilaku Nasabah meliputi Faktor Kebudayaan, Faktor Sosial, Faktor Pribadi Dan Faktor Psikologis (Kotler 2001:197).

\section{Pengujian Regresi Secara Simultan (Uji F)}

Hasil Uji Terhadap Koefisien Regresi Secara Simultan

\begin{tabular}{|c|c|c|c|c|c|}
\hline \multicolumn{6}{|c|}{ ANOVA $^{a}$} \\
\hline Model & $\begin{array}{c}\text { Sum of } \\
\text { Squares }\end{array}$ & Df & $\begin{array}{c}\text { Mean } \\
\text { Square }\end{array}$ & $\mathrm{F}$ & Sig. \\
\hline 1 Regression & 3,518 & 5 & 7,04 & $\begin{array}{r}29,4 \\
52\end{array}$ & $\begin{array}{r}, 000 \\
\mathrm{~b}\end{array}$ \\
\hline Residual & 2,245 & 94 & ,024 & & \\
\hline Total & 5,763 & 99 & & & \\
\hline
\end{tabular}

a. Dependent Variable: Y

b. Predictors: (Constant), $\mathrm{X}^{5}, \mathrm{X}^{4} \mathrm{X}^{3}, \mathrm{X}^{2}, \mathrm{X}^{1}$

Sumber : Data Primer Berdasarkan nilai $F$ pada Tabel 4.3 Tersebut Fhitung sebesar 29,452 dan nilai FTabel untuk $\alpha=0,05$ dengan derajat kebebasan $\mathrm{V} 1=5-1=4$ dan V2 $=100-5-1=94$ sebesar 2.31 yang dimana bisa dilihat bahwa Fhitung lebih besar dari FTabel $(29,452>2.70)$ maka dapat disimpulkan bahwa $\mathrm{HO}$ ditolak dan $\mathrm{Ha}$ diterima artinya dengan tingkat kepercayaan 95\% variabel independen faktor Pelayanan, Informasi, Reputasi, Pendapatan dan Minat Beli/ guna berpengaruh positif dan signifikan secara simultan (bersama-sama) terhadap Minat tabungan Investasi Cendekia Cabang Kota Bogor (Y). Hasil penelitian ini dikuatkan oleh penelitian Lila Nurhayati (2015) dan penelitian Eko Arianto wibowo (2015) bahwa variabel- variabel Independent berpengaruh secara simultan terhadap Minat Beli.

\section{Pengujian Regresi Secara Parsial (Uji t)}

Tabel 4.4 Pengujian Koefisien Regresi Secara Parsial

Coefficients $^{\mathrm{a}}$

\begin{tabular}{lcr|r|r|r}
\hline & & & \multicolumn{1}{c|}{$\begin{array}{c}\text { Standar } \\
\text { dized }\end{array}$} \\
& $\begin{array}{c}\text { Unstandardize } \\
\text { d Coefficients }\end{array}$ & $\begin{array}{c}\text { Coeffici } \\
\text { ents }\end{array}$ & & \\
\cline { 2 - 3 } Model & B & $\begin{array}{c}\text { Std. } \\
\text { Error }\end{array}$ & Beta & T & Sig. \\
\hline 1 (Constant) &, 189 &, 287 & &, 198 &, 843 \\
X1 &, 394 &, 081 &, 417 & 4,877 &, 000 \\
X2 &, 208 &, 081 &, 128 & 2,510 &, 134 \\
X3 &, 142 &,- 064 &, 150 & 2,209 &, 030 \\
X4 &,- 029 &, 057 &,- 036 &,- 502 &, 617 \\
X5 &, 317 &, 063 &, 383 & 5,068 &, 000 \\
\hline
\end{tabular}

a. Dependent Variable: minat beli (Y)

Sumber : Data Primer 2019

Berdasarkan Tabel 4.4 diatas dapat dilihat bahwa $t_{\text {hitung }}$ pada variabel faktor Pelayanan $\left(\mathrm{X}_{1}\right)$ sebesar 4,877 dan nilai tTabel untuk $\alpha=$ 0,05 dengan derajat kebebasan 100-5-1=94 sebesar 1,661 berarti $t_{\text {hitung }}>t_{\text {tabel }}(4,877$ $>1,661)$. Maka Ha diterima dan H0 ditolak, artinya faktor Pelayanan $\left(\mathrm{X}_{1}\right)$ berpengaruh positif signifikan secara parsial terhadap Minat Beli (Y). thitung pada variabel faktor Informasi $\left(\mathrm{X}_{2}\right)$ sebesar 2,510, dan nilai tTabel untuk $\alpha=0,05$ dengan derajat kebebasan 100-5-1=94 sebesar 1,661 berarti $t_{\text {hitung }}>t_{\text {Tabel }}(2,510>1,660)$. Maka Ha diterima dan HO ditolak, artinya 
Informasi $\mathrm{X}_{2}$ berpengaruh positif signifikan secara parsial terhadap Minat Beli, $t_{\text {hitung }}$ pada variabel faktor Reputasi $\left(\mathrm{X}_{3}\right)$ sebesar 2,209 , dan nilai $\mathrm{t}_{\text {Tabel }}$ untuk $\alpha=0,05$ dengan derajat kebebasan 100-5-1=94 sebesar 1,661 berarti $t_{\text {hitung }}>t_{\text {Tabel }}(2,209>1,660)$. Maka Ha diterima dan H0 ditolak, artinya Reputasi $\mathrm{X}_{3}$ berpengaruh positif signifikan secara parsial terhadap Minat nasabah, $t_{\text {hitung }}$ pada variabel faktor Religiusitas $\left(\mathrm{X}_{4}\right)$ sebesar -,502 dan nilai t Tabel untuk $\alpha=0,05$ dengan derajat kebebasan 100-5-1=94 sebesar 1,661 berarti $t_{\text {hitung }}>\mathrm{t}_{\text {Tabel }}(,-502<$ 1,660). Maka Ha ditolak dan H0 diterima, artinya Religiusitas $\mathrm{X}_{4}$ berpengaruh negatif secara parsial terhadap Minat nasabah. Sedangkan thitung pada variabel faktor Pendapatan $\left(\mathrm{X}_{5}\right)$ sebesar 5,068 , dan nilai $\mathrm{t}_{\text {Tabel }}$ untuk $\alpha=0,05$ dengan derajat kebebasan 100-5-1=94 sebesar 1,661 berarti $t_{\text {hitung }}>\mathrm{t}_{\text {Tabel }}(5,068>1,660)$. Maka Ha diterima dan $\mathrm{H} 0$ ditolak, artinya Informasi $\mathrm{X}_{5}$ berpengaruh positif signifikan secara parsial terhadap Minat nasabah.

\section{KESIMPULAN DAN IMPLIKASI}

Berdasarkan hasil dan pembahasan yang telah dilakukan dalam penelitian menunjukan bahwa variabel pendapatan berpengaruh positif dan signifikan secara langsung dan memiliki pengaruh yang paling tinggi diantara variabel-variabel lainnya. Hal ini menyatakan secara langsung bahwa variabel pelayanan menjadi faktor yang dominan mempengaruhi minat terhadap produk tabungan investasi cendekia. Argumen ini diperkuat karena banyak nasabah menyatakan bahwa pelayanan Bank Syariah Mandiri sangat baik, sopan dan santun.

\section{DAFTAR PUSTAKA}

A, Shimp, Terence (2003). Periklanan Promosi \& Aspek Tambahan Komunikasi Pemasaran.Terpadu, Jilid I (edisi 5), Erlangga Jakarta
Badan Pusat Statistik Nasional Produk Domestik Bruto (Diakses 18/12/2018 pukul 21.48) .

Carlos Kambuaya. 2015. pengaruh Motivasi, minat, kedisiplinan dan adaptasi diri terhadap prestasi belajar siswa peserta program informasi pendidikan menengah asal Papua dan Papua barat di kota Bandung. Vol.5.No.2.106-2010

Febriasti Hamidah. 2014. faktor-faktor yang mempengaruhi keputusan mahasiswa menabung di Bank Syariah Mandiri Yogyakarta

Uniyanti.2017. Faktor - faktor yang mempengaruhi minat nasabah menabung di bank Syariah ( Studi pada mahasiswa fakultas Ekonomi dan Bisnis Islam di UIN Alaudin).Skripsi

Rahmawati, 2011. Analisis metode bagi hasil produk tabungan investasi cendekia pada Bank Syariah Mandiri Kcp Katamso-Yogyakarta. Vol.VII No.1 Juli 2013

Nurul Khoiriah, 2011. Faktor-faktor yang mempengaruhi pertimbangan nasabah dalam memilih tabungan investasi cendekia pada PT. Bank Syariah Mandiri. Skripsi

Royan, Frans M. (2005). Marketing Selebritis. PT. Elex Media Komputindo. Jakarta.

Sugiyono, 2009, Metode Penelitian Kuantitatif, Kualitatif dan R\&D,: Alfabeta. Bandung

Sugiyono. 2010. Metode Penelitian Pendidikan Pendekatan Kuantitatif, kualitatif, dan R\&D. Alfabeta Bandung.

Sugiyono. 2013, Metodologi Penelitian Kuantitatif, Kualitatif Dan R\&D. Alfabeta Bandung

Sugiyono. 2014. Metode Penelitian Pendidikan Pendekatan Kuantitatif, Kualitatif Dan R\&D. Alfabeta Bandung. 